Katarzyna

\title{
Sawicka-Mierzyńska
}

Uniwersytet w Białymstoku

\section{Strategie autentyczności w prozie Ignacego Karpowicza (Sońka i Miłość)}

\section{Abstract \\ Strategies of Authenticity in Ignacy Karpowicz's Prose (Sońka and Miłośćc)}

The article concerns two books by Ignacy Karpowicz - Sonka from 2014 and Miłość from 2017, interpreted in an autobiographical context. This context serves not so much to highlight the links between these novels and the writer's experiences, but to recreate the "strategy of authenticity" used by Karpowicz in Sońka and the "strategy of honesty" used in Miłość. Both constitute a kind of "pact" (similar to the "autobiographical pact") concluded with the readers by the author. According to Olga Szmidt's deliberations, one of the inalienable elements of the "discourse of authenticity" is the undisclosed secret, which in Sońka's case turns out to be the protagonist's (homo) sexuality. The "strategy of honesty" is based on the assumption that the author does not hide anything from his audience. Both the interpretation of the two books contained in the text and the author's brief discussion of their reception show that the "strategy of authenticity" seems to be more artistically effective.

Słowa kluczowe: Ignacy Karpowicz, autentyczność, szczerość, autobiografizm, współczesna proza polska

Keywords: Ignacy Karpowicz, authenticity, honesty, autobiography, contemporary Polish prose 
[...] chcę żyć w świecie, w którym antidotum na wstyd to nie honor, ale szczerość.

Maggie Nelson, Argonauci

Na pierwszy rzut oka mogłoby się wydawać, że dwie ostatnie powieści Ignacego Karpowicza, czyli wydaną w 2014 roku Sońkę i Miłość z roku 2017 niewiele łączy, poza aktywizowaną w obu baśniową konwencją ${ }^{1} \mathrm{i}$ - co niebagatelne - motywem miłości ukazanej jako najważniejsze ludzkie doświadczenie. Akcja pierwszego utworu, rozpięta między Królowym Stojłem na Podlasiu a Warszawą, gdzie realizowany jest spektakl odtwarzający losy tytułowej bohaterki, to historia Soni, niepiśmiennej białoruskiej chłopki, która w czasie wojny zakochała się w niemieckim oficerze i urodziła jego dziecko. Zakazany romans miał dla Sońki tragiczne konsekwencje (gwałt, śmierć syna, męża i brata, samotna egzystencja kobiety wykluczonej z wiejskiej społeczności). To doświadczenie graniczne ukonstytuowało jednak nie tylko jej tożsamość, lecz także ontologiczną kondycję: dopiero spotykając Joachima, zaznała życia jako takiego, zyskała świadomość siebie, własnego ciała, nawiązała relacje ze światem. Równie ważnym bohaterem jest Igor/Ignacy, który staje się depozytariuszem, dysponentem i tłumaczem opowieści Soni. Dzięki jego translatorsko-reżyserskim zabiegom, skwapliwie ujawnianym przez narratora, możemy ją usłyszeć, tyle że w zniekształconej postaci, przełożoną bowiem nie tylko na język polski, ale także na zuniwersalizowane konwencje opowiadania o wojnie i miłości, z zastosowaniem narzędzi mających na celu poruszenie odbiorcy. Pojawiają się przy tym pytania o prawo artysty do cudzej opowieści, a zwłaszcza do czyjegoś cierpienia, poddawanego estetyzacji w obszarze sztuki. Igor jest tu istotny ze względu na rolę, jaką odgrywa wobec Sońki, niemniej jednak równie ważna w tej powieści jest historia rekonstrukcji jego tożsamości, a ściślej wypartego chłopsko-białoruskiego pochodzenia. Widomym znakiem jego reaktywacji jest ujawnienie dawnego imienia i nazwiska: w miarę rozwoju opowieści dowiadujemy się, że Igor Grycowski był wcześniej Ignacym Gryką.

W swojej ostatniej powieści Karpowicz mówi o prawie każdego człowieka do miłości, które z kolei staje się obligatoryjnym warunkiem partycypowania

1 Właściwie cała Sońka opiera się na zdekonstruowanej baśniowej strukturze, od pierwszych słów książki poczynając (,Dawno, dawno temu”), przez figurę jednego z głównych bohaterów Igora/Ignacego, który niczym książę z innego świata (tak zresztą postrzega go Sonia) zatrzymuje się na podlaskiej łące z powodu awarii pojazdu, po mówiące zwierzęta w roli pomocników. Baśniowe atrybuty powieści można by mnożyć. W Miłości formę baśni przybrała jedna z części książki, Dobro, które - jak deklaruje w wywiadzie udzielonym Dorocie Wodeckiej Karpowicz - ,jest możliwe tylko w bajce”. I. Karpowicz, Polskość jest jak Freddy Krueger - zawsze wraca i tnie, rozmawia D. Wodecka, „Gazeta Wyborcza”, 17.11.2017, https://wyborcza.pl/7,75517,22661462, ignacy-karpowicz-polskosc-jest-jak-freddy-krueger-zawsze.html?bo=1 [dostęp: 25.06.2020]. 
w Pięknie, Prawdzie i Dobru. Na książkę składają się trzy rozdziały tak właśnie zatytułowane: Piękno to stylizowane na Iwaszkiewiczowską prozę sceny z życia słynnego pisarza, jego kochanków i żony, Prawda to dziejąca się w niedalekiej przyszłości antyutopia przybliżająca zasady funkcjonowania świata, z którego wyeliminowano homoseksualizm, traktowany jako jednostka chorobowa, i indywidualną wolność jako zagrożenie dla funkcjonowania wspólnoty, Dobro natomiast to baśń o księciu i jego ukochanym, których rozdziela królewskie prawo, zaś finalnie łączy śmierć. Pomiędzy poszczególnymi rozdziałami, toczy się pierwszoosobowa opowieść, w której narrator symultanicznie relacjonuje historie swojej choroby i pobytu w szpitalu oraz rodzącej się miłości do Zbyszka, a wraz z nią - „odkłamywania” własnej, tłumionej dotąd seksualności. Mimo pozornej niespójności wszystkie części książki nie tylko się nawzajem dopełniają i oświetlają, ale także przenikają, zarówno na poziomie elementów świata przedstawionego (np. powracający motyw wielorybów, a to w postaci ceramicznej figurki, a to zwierząt towarzyszących podróży statkiem), jak i fabuły oraz warstwy metatekstowe. Dzieje się tak na przykład, kiedy Albertyna, bohaterka Prawdy, czytając powieść tajemniczego autora Janusza Suma, wyeliminowanego z oficjalnej historii literatury z powodu homoseksualizmu, zastanawia się, dlaczego ulubioną lekturą jednego z jej bohaterów jest bajkowe Dobro, albo kiedy dowiadujemy się, że Sum wszystkie swoje książki dedykował niezidentyfikowanemu „J”. Nie byłoby w tym nic znaczącego, gdyby nie to, że litera „J.”, bez dodatkowych objaśnień, została umieszczona na drugiej stronie samej Miłości. Ma rację Dariusz Nowacki, pisząc w swojej entuzjastycznej recenzji (a nie było ich wiele w takim tonie), że to książka, która wymaga „lektury wielokrotnej, bo jednorazowa nie pozwoli odkryć, z jak misterną konstrukcją mamy tu do czynienia [...]"2.

Przedstawione wyżej streszczenia grzeszą nadmiarem uproszczeń, zależało mi jednak na ich zaprezentowaniu, aby tym dobitniej na ich tle, eksponującym odmienność obu powieści, wybrzmiało pytanie o ich nieoczywiste punkty wspólne. Pierwszy z nich to wyraźne odwołania autobiograficzne. Karpowicz jest bardzo niechętny trybowi lektury, który polega na ich tropieniu, zarzucając mu tautologię, niemniej jednak z jakichś powodów ich niezamaskowane ślady (nazwy miejscowości, imiona i/lub nazwiska bohaterów) w swojej prozie pozostawia. Oczywiście, nie mamy tu do czynienia z klasycznym ,paktem autobiograficznym”, którego reguły sformułował Philippe

2 D. Nowacki, ,Miłość” Ignacego Karpowicza. M jak miłość, m jak majstersztyk, „Gazeta Wyborcza”, 20.11.2017, https://wyborcza.p1/7,75517,22669463,milosc-czyli-wyzwolenie-nowa-powiesc-ignacego-karpowicza.html [dostęp: 25.06.2020].

3 Zdaniem Karpowicza celem takiej interpretacji ma być udowodnienie ich obecności, z czego nic nie wynika. Na temat kontekstów autobiograficznych twórczości Ignacego Karpowicza pisałam w książce Poruszyć miejsce. Obraz Białegostoku w twórczości Sokrata Janowicza i Ignacego Karpowicza, Białystok 2018, s. 181-187. 
Lejeune, raczej z „przestrzenią autobiograficzną” i „paktem fantazmatycznym”, który uprawnia czytelników i badaczy do traktowania tych „powieści nie tylko jako zmyślenia odsyłającego do prawd o «naturze człowieka», lecz również jako fantazmatów niosących prawdę o autorskim indywiduum"4. Małgorzata Czermińska we wstępie do nowego wydania swojej już klasycznej książki, w której sformułowała i zastosowała jako narzędzie interpretacji model ,autobiograficznego trójkąta”, zauważa, że każdy „,[t]wórca tekstu, który sugeruje (albo wręcz nakazuje, lub przeciwnie - stara się ukryć, ale jednak ryzykuje taką sugestię) czytelnikowi odniesienie do wiedzy pozaźródłowej, przyjmuje postawę autobiograficzną"s. Odwołania autobiograficzne będą kluczowe w przypadku obu tych powieści, gdyż zasadniczym, na różne sposoby realizowanym tematem każdej z nich (i to właśnie drugi ważny punkt wspólny tych książek) jest kwestia autentyczności, a w jej ramach - problem artykulacji tożsamości seksualnej. Chcę od razu poczynić zastrzeżenie, że moim celem nie jest interpretacja Sońki i Miłości jako literackich komentarzy do coming outu autora, aczkolwiek homoseksualność bohaterów jego prozy, siłą rzeczy odnosząca się do doświadczeń samego Karpowicza ujawnianych przez niego w wywiadach, będzie tu istotna.

Dlaczego autentyczność niejako automatycznie aktywizuje upodmiotowienie figury autora i angażuje go w proces interpretacyjny? Przypomnijmy genialny w swej prostocie ,autobiograficzny trójkąt” Czermińskiej. Jego wierzchołki stanowią ,ja” (autorskie), „ty” (czyli odbiorca) i ,świat”, a „powierzchnię" - inaczej jeszcze rzecz ujmując: obszar realizacji - tekst. Analizując poziom intensywności uobecniania się w nim każdego z tych trzech czynników, badaczka wyróżnia model autobiograficznego wyznania, wyzwania i świadectwa. Te kategorie dotyczą oczywiście literatury autobiograficznej, sam „trójkąt” może jednak posłużyć, niczym blejtram, do rozpięcia na nim innych relacyjnych pojęć, choćby takiego, jak autentyczność. Wydarza się ona bowiem, jak sądzę, w obszarze między ,ja” a „ty” - angażując w ten układ „świat”, mówilibyśmy raczej o realizmie czy mimesis. To przekonanie jeszcze się wzmocni, gdy - nadal w ślad za Czermińską - sięgniemy do Arystotelesa, który wyróżnił w retoryce trzy rodzaje środków perswazji, „skupione wokół trzech biegunów. Są to środki nastawione przede wszystkim na osobę mówiącego (ethos), na poruszenie słuchaczy (pathos) i na samą logikę faktów, przedstawianych w mowie (logos)"

Idąc tym tropem, można pokusić się o stwierdzenie, że z autentycznością wiąże się również pewien etos, którego gwarantem intuicyjnie czynimy autora, z kolei konsekwencją zastosowania jej jako strategii pisarskiej okazu-

4 P. Lejeune, Pakt autobiograficzny, przeł. W. Labuda, „Teksty” 1975, nr 5, s. 46.

5 M. Czermińska, Autobiograficzny trójkąt. Świadectwo, wyznanie, wyzwanie, wyd. 2 zmien., Kraków 2020, s. 8.

6 Ibidem, s. 32-33. 
je się „poruszenie” wywołane w odbiorcach. W bardzo przekonujący sposób o efekcie autentyczności opowiedział mi niedawno znakomity poeta średniego pokolenia Piotr Janicki.

Kiedy mi opisujesz samochód, z czego się składa, to ja nie obcuję z samochodem, a z jego opisem. Ale kiedy mnie łapiesz za rękę i krzyczysz: to jest [...] zapierające dech, to wtedy ja współodczuwam, jestem naprzeciwko rzeczy, o której mi mówisz, i sam jej doświadczam. Zakładamy, że nigdy nie przejadę się samochodem7.

Przytaczam te słowa trochę na prawach anegdoty, ale też ze względu na to, że Janicki dość precyzyjnie wyraża tu niezwykle istotną kwestię: nawet najbardziej detaliczny, rozbudowany i realistyczny, pobudzający wyobraźnię opis nie wywoła w odbiorcy poczucia autentyczności, ma ona bowiem charakter zdarzeniowy, dzieje się między nim a twórcą i jego tekstowymi/artystycznymi reprezentacjami, przy zakładanym zaangażowaniu emocjonalnym obu stron. Ten swoisty pakt między pisarzem a odbiorcą, jakim jest deklaracja bądź samo pragnienie autentyczności, niesie ze sobą - na co zwraca uwagę Olga Szmidt - wiele zagrożeń, a wśród nich ryzyko odrzucenia przez krytyków, czytelników, zarzut pretensjonalności czy wreszcie - nieautentyczności ${ }^{8}$. Z nich wszystkich zdaje sobie sprawę Karpowicz, a nawet je tematyzuje w Sońce, i właśnie autentyczność - jako strategia artystyczna i literacka czy też, mówiąc językiem zapożyczonym z powieści, ,potworna klisza” - to jeden z głównych tematów tej książki. Jej warstwa metatekstowa jest, w moim przekonaniu, równie ,poruszająca”, by trzymać się wprowadzonej wcześniej nomenklatury, co dramatyczne losy bohaterów.

Jak zauważa Szmidt w podsumowaniu książki Autentyczność: stan krytyczny:

[...] autentyczność nie może ujawnić się w spójnym i niezaburzonym niczym kształcie, a wręcz przeciwnie - zmuszona jest uwikłać się w sprzeczności, niejasności, wieloznaczności, aby odkryć coś, co wcześniej jest niedostępne, a może nawet nieistniejące 9

7 P. Janicki, Mail do autorki, 20.06.2020.

8 O. Szmidt, Autentyczność: stan krytyczny. Problem autentyczności w kulturze XXI wieku, Kraków 2019, s. 12. Autorka lokuje swoje rozważania o autentyczności przede wszystkim w kontekście modernizmu, sama jednak to konkretne odniesienie niweluje, eksponując płynność przejścia nowoczesności w ponowoczesność i ich wzajemne uwikłania. Dotyczy to nie tylko badawczych deklaracji, ale także części interpretacyjnej, w których za pomocą sformułowanych wcześniej kategorii analizuje dorobek Mariny Abramović, Resztki Toma McCarthy’ego czy amerykańskie seriale feministyczne, których ,środowiskiem naturalnym" wydaje się postmodernizm. To uprawnia mnie do zastosowania kategorii uruchomionych przez badaczkę do interpretacji prozy Ignacego Karpowicza.

9 Ibidem, s. 330. 
Taka, uwikłana w sprzeczności jest też struktura narracyjna Sońki. Jak to ujął Ryszard Koziołek, przekraczając wraz z Igorem próg chaty tytułowej bohaterki, ,tracimy narracyjny grunt" 10 i bynajmniej nie odzyskujemy go w toku lektury; zamknąwszy książkę, nadal nie wiemy, kiedy mieliśmy do czynienia z przetłumaczoną na język polski i wielokrotnie zredagowaną opowieścią Soni, a kiedy była to relacja $\mathrm{z}$ wyreżyserowanego na jej podstawie przedstawienia. Odrealnienie biografii Sońki zostaje zasygnalizowane już w pierwszych słowach powieści („Dawno, dawno temu”), aktywizujących baśniową konwencję, pozornie sytuującą się na antypodach autentyczności. Jak pisze Koziołek:

[...] świat i życie, przy których nas nie było, są nam dostępne tylko jako baśń, czyli to, co się opowiada i co istnieje wyłącznie jako opowiadanie. Nazywamy to biografią, religią, nauką, sztuką, historią, interpretacją, niemniej treść tych nazw będzie dla nas znana i ważna dopiero wtedy, kiedy staną się baśnią, gdy nie będziemy pytać o ich prawdziwość, ponieważ prawdziwie je przeżyjemy. Żeby tak się stało, trzeba to d o br ze opowiedziećn ${ }^{11}$.

„Dobrze opowiedzieć” oznacza w tym przypadku nieustannie obnażać mechanizmy samej opowieści czy też, jak to ujął Łukasz Wróbel ${ }^{12}$, procesów semiozy - przemiany ciała w znak. Karpowicz robi wszystko, żebyśmy zrozumieli, że nie mamy dostępu do Soni jako takiej. Jak słusznie zauważa Koziołek:

W wypowiedziach Sońki umieścił Karpowicz sporo wyrażeń białoruskich charakterystycznych dla gwary białostockiej, ale i tak nie rozstrzygniemy, czy to autentyczność skonstruowana dla efektu autentyczności, czy oddany uczciwie przez Igora sposób mówienia Sońki ${ }^{13}$.

Gwałtowna dekonstrukcja baśniowej iluzji pojawia się na samym początku książki, na osiemnastej stronie, w momencie, kiedy już daliśmy się ponieść/ zwieść narracji:

Dawno, dawno temu - mówi Sonia, a zgromadzeni poddają się jej głosowi, wpatrują się w jej twarz, historia Soni wyrzuca ich poza nawias czasu, a potem owacja na stojąco (Igor trusio staje obok aktorki staruszki, głowę pochyla ku czubkom swoich butów ze skromnością nieco zbyt fotogeniczną); przynajmniej kwadrans

10 R. Koziołek, Esesman, mój bliźni [w:] idem, Dobrze się myśli literatura, Wołowiec 2016, s. 175.

11 Ibidem, s. 180.

12 Ł. Wróbel, ,, Sońka”, czyli spokój czasu przeszłego. O najpiękniejszej powieści Ignacego Karpowicza, „Kultura Liberalna” 2014, nr 29, https://kulturaliberalna.pl/2014/07/22/ sonka-karpowicz/ [dostęp: 26.06.2020].

13 R. Koziołek, op.cit., s. 182. 
trwają oklaski, damy mdleją, kawalerowie nie wstydzą się łez w oku i na policzku wypielęgnowanym. Sukces ${ }^{14}$.

Już do końca narrator będzie symultanicznie prowadził te przeplatające się opowieści: o Soni, spektaklu i jego dandysowatym reżyserze, a nawet o ewoluującej reakcji na przedstawienie, kiedy to sceptyczni krytycy zmieniają zdanie pod wpływem entuzjastycznie reagującej, wzruszonej publiczności. Intersemiotyczny przekład spektaklu na język powieściowy to zresztą nie ostatnia z narracyjnych ,otulin”/metatekstowych warstw spowijających postać niepiśmiennej chłopki, zamienionej dzięki tym wszystkim zabiegom w „,białoruską Szeherezadę"15, w kilku scenach widzimy bowiem Igora/Ignacego, który ogląda filmową rejestrację przedstawienia:

Oglądał po raz bodaj dziewiąty scenę Spaceru pod Most.

Teraz robi pauzę i zoom-in na twarz aktorki. Wygasza tło. Jej twarz zastyga, wypełniając cały ekran. On patrzy w jej półzamknięte oczy.

Ostatni tydzień spędził na wpatrywaniu się w jej twarz. Ta twarz go obezwładnia i rozbraja szczerością czy też prawdą. Widzi pracę charakteryzatorów, widzi scenę, widzi wszystkie nieścisłości i umowności, a mimo to wierzy w tę twarz.

Zwalnia pauzę. Kobieta opada na sztuczną trawę. Oddycha niezauważalnie. Siada przy niej aktor grający Joachima. Rozbierają się. Kurtyna. Cóż jest złego w byciu późniejszym niż oryginał? ${ }^{16}$

Pokazując odczucia Igora/Ignacego, Karpowicz doskonale oddał stan, w którym znajdują się czytelnicy książki: wiemy, że mamy do czynienia z iluzją, twarz aktorki miesza nam się ze stylizowanymi na prawosławne ikony opisami Soni, ale wzruszamy się naprawdę. Żeby znowu powołać się na Koziołka: „Im bardziej oddzieleni od bohaterów, tym mocniej czujemy ich obecność"17. Paradoksalnie zatem efekt autentyczności zostaje osiągnięty dzięki zmaksymalizowaniu dystansu odbiorców wobec świata przedstawionego i bohaterów oraz wytworzeniu tym samym ich swoistej „komitywy” z autorem. Przy takim stopniu obnażenia reguł literackiej iluzji zaczynamy się czuć tak, jakbyśmy dysponowali niemal tymi samymi co pisarz kompetencjami. Przypomnę cytowanego wyżej Janickiego - autor symuluje sytuację, w której bierze nas za rękę i mówi: patrzcie! Nie przypadkiem zresztą zapewne jedno z mediów

14 I. Karpowicz, Sońka, Kraków 2014, s. 18.

15 P. Czapliński, Nowa powieść Ignacego Karpowicza. Jak wyjść z kopalni trupów, „Gazeta Wyborcza”, 20.05.2014, https://wyborcza.pl/1,75410,15992693,Nowa powiesc_Ignacego_Karpowicza_Jak_wyjsc_z_kopalni.html [dostęp: 26.06.2020].

16 I. Karpowicz, Sońka, s. 79.

17 R. Koziołek, op.cit., s. 185. 
„parawanów”"18, rozstawionych przez Karpowicza między nami a Sonią, to teatr. Jak przypomina Beata Gontarz, za Samuelem Weberem, etymologia słowa „teatr” jest taka sama, jak wyrazu „teoria”: to greckie „thea”, czyli miejsce, z którego się patrzy lub obserwuje ${ }^{19}$. Pisałam już, odwołując się do "trójkąta” Czermińskiej, że autentyczność wydarza się między autorem a odbiorcą i wymaga pewnego etosu - tak właśnie dzieje się w Sońce. Skoro autor, oczywiście ukryty za tekstem, aż tak się przed nami w nim obnaża: z problemami, jakich przysparza mu materia literacka, z etycznymi rozterkami, własną niepewnością, a nawet nieporadnością, zaczynamy przypisywać mu szczerość i uczciwość, a rezultat jego wysiłków traktować jako coś nadzwyczaj autentycznego. Gwarantem tej autentyczności staje się on sam i relacja, w jaką nas uwikłał, ekskluzywna „loża”, którą dla nas zbudował ponad powieściowym teatrem, byśmy mogli w niej dyskretnie celebrować swoje wzruszenie.

Podejmując próbę scharakteryzowania stylu „tekstów (o) autentyczności”, Olga Szmidt wskazuje na częste występowanie w nich takich środków, jak patos, hiperbola, parabaza i paradoks ${ }^{20}$. Wszystkie odnajdziemy w Sońce o parabazach była mowa wyżej, patos pojawia się choćby w ostatniej scenie, gdzie wszyscy zostajemy zaproszeni, jako dzieci Soni, do wspólnego odmówienia kadiszu na jej teatralnym pogrzebie, hiperbolę znajdziemy w konstrukcji postaci tytułowej bohaterki, kumulującej kolejne piętra wykluczeń i stygmatów, niczym żeńska wersja Hioba, bez męskiej buty i boskich interwencji. Są to jednak zaledwie środki służące realizacji strategii autentyczności (wolę to określenie, niż słowo „dyskurs”, którego używa Szmidt), podczas gdy jej podstawowym atrybutem jest paradoks, a warunkiem - szeroko rozumiane „medium”, które stanowi dla niej barierę: „Postulat autentyczności ma więc rację bytu o tyle, o ile przeciwstawia się temu, co zastane i powszechne, temu, co uważane za dotychczas konwencjonalne i stanowiące największą przeszkodę"21 - pisze Szmidt. Nieco dalej czytamy:

Autentyczność istnieje o tyle, o ile powstaje w relacji ze sztucznością (sztuką, literaturą, społeczeństwem, widowiskiem). Przezwyciężanie tego obciążenia jest częścią twórczości, poszukiwanie wyjścia z klinczu - niezmienną podmiotową utopiąą.

18 I. Karpowicz, Sońka, s. 67.

19 B. Gontarz, Meandry etyczne podmiotu w ,Sońce” Ignacego Karpowicza [w:] „,Ja” $w$ przestrzeniach aksjologicznych. Z problematyki podmiotowości w literaturze XIX-XXI wieku, red. L. Zwierzyński, M. Wiszniowska, P. Paszek, Katowice 2017, s. 182.

20 O. Szmidt, op.cit., s. 237.

21 Ibidem, s. 242.

22 Ibidem, s. 246. 
Jako dwa podstawowe źródła tych przeszkód, barier i ograniczeń badaczka wskazuje, za Marshallem Bermanem, „klasę społeczną” i ,płeć”23, co modelowo realizuje konstrukcja postaci Soni. W obszarze „płci” mieści się fakt, że jest ofiarą kazirodczych praktyk ojca, później - gwałtu dokonanego przez członków społeczności, z której już na zawsze zostanie wykluczona jako zdrajczyni (romans z Niemcem); matką bękarta, „szeptuchą”, bytem właściwie odpodmiotowionym, zależnym od woli mężczyzn. W tym wszystkim Sonia ma jednak, jak sugeruje Koziołek, ,,prawo do fikcji”, niekoniecznie własnej, bo zapośredniczonej przez patriarchat, ale ugruntowanej i rozpoznawalnej ${ }^{24}$ : opowieść o kobiecym wykluczeniu i wiktymizacji to przecież jedna z lepiej znanych naszej kulturze narracji. Aby aktywizować na tym polu strategię autentyczności, a więc także indywidualizacji, wystarczy ujawnić grę z konwencjonalnymi ujęciami tego typu motywów lub dodać do nich jakiś niestandardowy element, na przykład baśniowość czy obrazowanie nawiązujące do ikony. Wydaje mi się, że problem z artykulacją wyjątkowości doświadczenia Soni zaczyna się w momencie, gdy do głosu dochodzi jej seksualność i zmysłowość, stanowiące podstawę relacji z Joachimem Castorpem. Ich miłość obywa się bowiem bez słów i bez jakichkolwiek akceptowalnych społecznie kontekstów, a przy tym staje się narzędziem upodmiotowienia Soni, o czym pisałam na początku.

Na kobiecość tytułowej bohaterki nakłada się jednak jeszcze szeroko rozumiana „klasa”, której Sońka jest reprezentantką (na poziomie społecznym) i tu już pojawiają się bariery, których nie udałoby się pokonać bez „tłumacza” i zapożyczeń z innych, bardziej oswojonych języków. Jest więc Sonia niepiśmienną, ubogą chłopką, Białorusinką zamieszkującą pograniczne tereny Polski, która wprawdzie rozumie polski język, ale sama się nim nie posługuje. Wszystko to czyni ją osobą wykluczoną zarówno z komunikacyjnej wspólnoty, jak też z oficjalnej historii, ufundowanej na martyrologicznych podstawach, z gotowymi kliszami opowieści, na przykład dotyczących wojny, która z perspektywy Soni była walką Polaków z Niemcami. Powtórzmy: jeśli autentyczność zakłada artykulację jakiejś podmiotowej indywidualności, Sonia nie ma na nią szans - potrzebny jej ,czuły narrator”. „Heta usio ni majo, zusim”, powie w ostatnim zdaniu książki Sońka albo grająca ją aktorka, sygnalizując tym samym, że usłyszeliśmy opowieść, która nawet nas poruszyła, ale to nie znaczy, że jakkolwiek dotknęliśmy fenomenu jej bohaterki.

Jak zauważa Szmidt, „niezbywalnym elementem dyskursu autentyczności” jest „strategia nieujawniana sekretu, którego w istocie nie posiadł. To niekończące się okrążanie problemu i uwodzenie czytelnika, bez nadziei spełnie-

23 Zob. ibidem, s. 115.

24 Jak pisze Ryszard Koziołek, dzięki nam Sońka „ma prawo do fikcji. Nie własnej jednak". Idem, op.cit., s. 181.

25 I. Karpowicz, Sońka, s. 197. 
nia obietnicy”26. „Sekret” Soni nie zostaje ujawniony i rozszyfrowany, wiemy jednak przynajmniej, gdzie go zlokalizować, wokół czego krążymy i jaka obietnica nie została spełniona. Zupełnie inaczej rzecz ma się z Igorem/Ignacym. Jak wspominałam, w miarę rozwijania się opowieści o Soni dokonuje się też proces „odkłamywania” jego własnej tożsamości: okazuje się, że zanim został znanym warszawskim reżyserem, był prawosławnym, urodzonym na podlaskiej wsi chłopcem, zgodnie z wolą rodziców poddanym/poddającym się zwieńczonemu sukcesem procesowi samopolonizacji. Kwestia jego prawa do autentyczności zostaje zatem także rozegrana na poziomie „klasowym”. Co jednak z jej drugim kluczowym obszarem, czyli seksualnością?

W wielu fragmentach książki, stanowiących relację z przeżyć wewnętrznych Igora/Ignacego, możemy się natknąć na znaczące, ukryte za różnego typu zaimkami przemilczenia i niedookreślenia. Dowiadujemy się, że odtwarzając historię Soni, musi on zawalczyć również o własną prawdę oraz że dzięki spotkaniu ze staruszką uświadomił sobie dotkliwą tęsknotę za czymś, czego nigdy nie zaznał ${ }^{27}$.

Reżyser i tłumacz opowieści Soni zarysowuje też wyraźną paralelę między jej i własnym doświadczeniem, określając punkty wspólne: narząd mowy (problemy oczywiście pojawiają się w momencie artykulacji), emocje, w tym strach przed upokorzeniem, oraz płeć28.

Niekiedy przekładanie myśli Soni sprawiało mu wielką trudność. Teoretycznie nie powinno to stanowić problemu. Jej język i jego nie są zbyt odległe, mieszkają w podobnych jamach, ta sama śliskość, to samo żebrowane podniebienia, ten sam strach przed upokorzeniem. Jej emocje wydają mu się dostępne. Jej płeć, osłabiona wiekiem, nie jest całkowicie obca. A jednak. A jednak nie jest to takie proste, jakby wynikało z sumy podobieństw.

Nieraz czuł, że opowieści Soni odbiera coś cennego. Czuł się jak kustosz w muzeum cudzych wspomnień, jak horolog przy rozłożonym mechanizmie. Dopiero gdy się przełożyło te wspomnienia na własne doświadczenie, wyłaniało

26 O. Szmidt, op.cit., s. 253.

27 „W jaskrawej iskrze, która przeskoczyła na niego z Jozika Pasterza Myszy [kot Soni - dop. K.S.M.], pojął, że musi pamiętać więcej nawet, niż Sonia opowiadała, że musi pamięć zaprząc $w$ teatralny lub powieściowy kierat, by siebie ocalić, by wreszcie opowiedzieć jakąś prawdę, zawalczyć o coś. Chociaż to akurat przeczuwał chyba od samego początku, już od progu".

„Igor poczuł nieokreśloną bliżej tęsknotę. Jakby tęsknił do czegoś, czego nie skosztował, a co już stracił. Albo do tęsknoty za ciągłością, za nitką nawiniętą na kłębek, bez supełków". I. Karpowicz, Sońka, s. 59, 101.

${ }_{28} \mathrm{Na}$ temat rangi spotkania Igora/Ignacego z Sonią, interpretowanej narzędziami krytyki feministycznej, zob. G. Zawojska, ,Sońka” Ignacego Karpowicza w kontekście wybranych koncepcji feminizmu postmodernistycznego, „Białostockie Studia Literaturoznawcze" 2019, nr 14, s. 219-233. 
się coś zrozumiałego, równocześnie jednak jasne stawało się to, że po drodze coś umykało.

Autentyczność to jednak potworna klisza ${ }^{29}$.

$\mathrm{Na}$ poziomie deklaracji Igora/Ignacego bliskość płci Sońki wynika z jej „osłabienia wiekiem”. Co jednak, gdyby istniał też inny, niezwerbalizowany powód tego podobieństwa, czyli potencjalny homoseksualizm bohatera, kierujący jego pożądanie w tym samym co kobiece kierunku? Uzasadnienia tej intuicji możemy szukać w obszarach pozatekstowych, choć niekoniecznie sięgając po konteksty autobiograficzne. W rozmowie z Magdaleną Mołek Karpowicz powiedział bowiem, że Gesty z 2008 roku napisał po to, żeby zrozumieć Igo$\mathrm{ra}^{30}$, z kolei jeden z plików w komputerze Grzegorza, głównego bohatera tej powieści, co nie bez znaczenia - „scenarzysty i reżysera” - nosi nazwę „sonia.doc”. Odkrycie, którego dokonuje na swój temat tuż przed śmiercią Grzegorz, dotyczy właśnie jego tożsamości seksualnej, a ostatnia bliska relacja, jaką buduje, jest z mężczyzną. To związek ledwie naszkicowany, przerwany odejściem bohatera, tak jakby Karpowicz jeszcze nie miał odwagi opowiedzieć o spełnionej, skonsumowanej homoseksualnej miłości.

Kiedy czytamy wyznanie Igora/Ignacego, że po przełożeniu wspomnień Soni na jego własne doświadczenie „,po drodze coś umykało”, koncentrujemy się na Sońce i na tym, co zostało bezpowrotnie utracone $\mathrm{z}$ jej historii, tymczasem równie dobrze może to być „,coś” z obszaru prawdy o jej tłumaczu. Warto w tym kontekście przywołać scenę, która jest ulubionym, wielokrotnie odtwarzanym przez Ignacego fragmentem spektaklu, a jednocześnie najbardziej go rani:

Pierwsza Scena Przebudzenia. Według Igora to jedna z najpiękniejszych scen w Królowym Stojle. Nie oglądał jej często. Sprawiała mu głęboki ból. Zazdrościł Miszy, że kochał. Zazdrościł Soni, że kochała i była kochana ${ }^{31}$.

Wniosek jest oczywiście prosty: reżyser zazdrości swoim bohaterom uczucia, którego sam nigdy nie zaznał, bardziej skomplikowane okazują się przemilczane powody tego braku.

Wreszcie cytat ostatni, który stanowi wręcz dosłowną ilustrację przyświecającej moim rozważaniom tezy, że obszarem najgłębiej ukrytym pod wszystkimi metatekstowymi warstwami Sońki jest (homo)seksualność narratora, któremu z pewnością nie bez przyczyny Karpowicz użyczył nie tylko własnego imienia, ale także miejsca urodzenia (Słuczanka). Niemal na

29 I. Karpowicz, Sońka, s. 108.

30 Wypowiedź pisarza podczas spotkania w ramach Big Book Festival (Warszawa, 23-25 czerwca 2017 r.), prowadzonego przez Magdę Mołek.

31 I. Karpowicz, Sońka, s. 148. 
ostatnich stronach książki Igor/Ignacy wyznaje, co ważne, w pierwszej osobie (jak widzieliśmy, zwykle jego słowa przytaczane były za pośrednictwem trzecioosobowej narracji): „A na mojej skórze, na kroczu i wszędzie czuję coś dziwnego, kwasowe kąsanie mrówek: jakbym był opowiadany i równocześnie opowiadał”32. Karpowicz mógł pozostać przy określeniu „wszędzie”, mógł napisać: „na całym ciele”, a jednak z premedytacją użył, wprowadzającego nawet pewien dysonans, bardzo konkretnego, niepozostawiającego wątpliwości co do swego charakteru i lokalizacji desygnatu, słowa „krocze”. Tym samym pisarz sygnalizuje, że - by zastosować terminologię Germana Ritza - ukrytą zasadą organizującą tekst Sońki jest „niewypowiadalne pożądanie", z którym zarazem wiąże się imperatyw/konieczność jego wyrażenia ${ }^{33}$. To aż zaskakujące, w jak dużej mierze powieść Karpowicza, jeśli aktywizujemy wobec niej strategię interpretacji określoną przez Wojciecha Śmieję jako lekturę „równolegle homoseksualną" ${ }^{34}$, spełnia kryteria prozy sublimacyjnej, sformułowane przez Ritza na podstawie twórczości Jarosława Iwaszkiewicza, Wilhelma Macha i Tadeusza Brezy, czyli pisarzy modernistycznych. Kwestia poziomu tabuizacji homoseksualizmu i społecznych oraz wewnętrznych, subiektywnych, podmiotowych barier (oczywiście to, co jednostkowe pozostaje w ścisłej zależności z tym, co społeczne), kształtujących ramy jego ekspresji, czyli ramy dopuszczalnego dla niego dyskursu autentyczności, okazuje się zatem istotniejsza niż cezura między nowoczesnością a ponowoczesnością, oddzielająca twórczość Karpowicza od dzieł jego poprzedników. Igor/Ignacy, niemal wzorem bohaterów ich prozy, opuszcza „miejskie, cywilizowane otoczenie”, by szukać „wewnętrznej przemiany”, której „,punktem ośrodkowym będzie spotkanie seksualne, niewypowiadalne pożądanie" ${ }^{35}$. Co ciekawe, geograficznie zwykle są to pogranicza, czyli obszary etnicznie zmieszane, na których polskość nie stanowi jedynej dominanty, na przykład takie, jak wschodnia część Podlasia. To ważne, bo - jak to ujmuje Śmieja, rekapitulując myśl Gombrowicza jako jednego z ważnych patronów polskich pisarzy

32 Ibidem, s. 196.

33 Zob. G. Ritz, Niewypowiadalne pożądanie a poetyka narracji, przeł. A. Kopacki, „Teksty Drugie” 1997, nr 3, s. 43-60.

34 Taki tryb lektury Wojciech Śmieja proponuje wobec Panien z Wilka Jarosława Iwaszkiewicza, polemizując z Germanem Ritzem, który widzi w tym opowiadaniu przykład przedemancypacyjnej literatury homoseksualnej. Jak twierdzi Śmieja: „Odczytywanie opowiadania jako tekstu jedynie homoseksualnego, polegające na odkrywaniu kolejnych ekwiwalencji, substytucji, niedomówień i znaków, będzie miało charakter redukcjonistyczny, jednostronny, partykularny, by nie rzec: nadmiernie zideologizowany. [...] Jeśli nasza lektura ma aktualizować wszystkie jego sensy, możemy opowiadanie czytać co najwyżej w sposób «podwójny», tzn. jako opowiadanie t a k ż e, r ó w n o c z e śn i e, r ó w n o l e g l e homoseksualne [...]". Idem, Literatura, której nie ma. Szkice o polskiej literaturze homoseksualnej, Kraków 2010, s. 24.

35 G. Ritz, op.cit., s. 49. 
gejowskich - polska tożsamość narodowa została zbudowana na lęku przed homoseksualizmem ${ }^{36}$, który stanowi w niej coś na kształt pęknięcia. Nic dziwnego zatem, że artyści, poszukując ekwiwalentów dla oddania homoseksualnej kondycji swoich bohaterów (czy swojej własnej), sięgają po postaci reprezentujące mniejszości, między innymi ze względu na ich subwersywny wobec homogenicznego modelu polskości potencjał.

Jak czytamy u Ritza, po kulminacyjnym momencie i eskalacji niewypowiadalnego pożąanania dochodzi do dekonstrukcji narracji i procesów tożsamościowych. Dekonstrukcja ta dokonuje się

[...] na płaszczyźnie kompozycji tematu środkami akcji zastępczej, która jednak nie nabiera własnego znaczenia. Osiąga się to poprzez niemal inflacyjne powiększanie zespołu występujących osób. [...] Symultana staje się zasadą narracyjną. Brak czy też niemożność sygnifikacji prowadzi do wydłużania szeregu kolejnych sygnifikantów, szeregu analogii - mówiąc słowami Lacana - metonimii. Jest to metonimiczny strumień pożądania, który zostaje wyjęty spod „,prawa ojca” lub też wyparty poza obręb działania tego prawa i który nie ustanawia już żadnej tożsamości ${ }^{37}$.

W Sońce taką kluczową analogią staje się metonimiczna, oparta na zasadzie sublimacji relacja między tytułową bohaterką a Igorem/Ignacym. To na Sonię ceduje on swoje poczucie wykluczenia, ale też ona jest tą, której pożądanie pozwala wyjść spod „prawa ojca" i bynajmniej nie stracić przez to tożsamości, wprost przeciwnie. Problemem nie jest jej nieukonstytuowanie się, tylko nieprzekładalność i wykluczenie. Sądzę też - choć to intuicja problematyczna, bo dotyczy kwestii procesu twórczego - że to, co w prozie sublimacyjnej początku XX wieku działało na poziomie nieświadomym (a przynajmniej nie do końca przez autora uświadomionym), kształtując, a właściwie dekonstruując narracyjną strukturę, w prozie Karpowicza jest konsekwentnie realizowaną strategią. Sońka wydaje mi się też ważna jako rodzaj społecznej diagnozy: strategię autentyczności w Polsce XXI wieku łatwiej jest stosować w obszarze różnic i barier klasowych niż seksualnych, które Karpowicz świadomie poddaje w swojej powieści procesom sublimacji i tabuizacji ${ }^{38}$.

\footnotetext{
36 W. Śmieja, op.cit., s. 116.

37 G. Ritz, op.cit., s. 49.
}

38 Dla kontrastu warto przywołać esej Didiera Eribona Powrót do Reims. Autor wyznaje tam, że w środowisku francuskich elit intelektualnych i artystycznych, do których trafił drogą awansu społecznego, łatwiej jest przyznać się do homoseksualizmu niż do chłopskiego czy robotniczego pochodzenia. Zob. D. Eribon, Powrót do Reims, przeł. M. Ochab, Kraków 2019. 
Jak napisał o ostatniej powieści Ignacego Karpowicza Dariusz Nowacki:

Miłość z Miłości ma to do siebie, że może się pojawić dopiero kiedy zostanie poprzedzona - by tak rzec - fundamentalną robotą tożsamościową. Trzeba tej miłości utorować drogę, czyli zrobić porządek ze sobą, zrywając z kłamstwem i przezwyciężając wstyd ${ }^{39}$.

Część tej „fundamentalnej roboty” została już wykonana (kwestie „klasowe”), „kłamstwo i wstyd”, które należy przezwyciężyć, wiążą się z seksualnością. W słynnym eseju Imitacja i niepostuszeństwo ptciowe Judith Butler formułuje zasadnicze pytania dotyczące jej kondycji i tożsamości jako lesbijki:

Podczas konferencji o homoseksualności w 1989 roku nagle uświadomiłam sobie, że mówię moim znajomym, iż wyjechałam do Yale, żeby być lesbijką, co nie znaczyło oczywiście, że wcześniej nią nie byłam, tylko że dopiero wtedy, zgodnie z kontekstem, w jakim o tym opowiadałam, byłam nią w szerszy i pełny sposób. [...]

Jak to się dzieje, że mogę zarazem nią być i starać się nią być w tym samym czasie? Kiedy i gdzie moje bycie lesbijką wchodzi w grę i kiedy owo odgrywanie lesbijki konstytuuje coś takiego, jak moje bycie sobą? Powiedzieć, że ja „odgrywam” to, że jestem lesbijką, nie oznacza, że nie jestem nią „naprawdę”; idzie raczej o to, jak i gdzie odgrywanie tego bycia jest sposobem, w jaki to „bycie” zostaje ustanowione, zinstytucjonalizowane, wprowadzone w obieg i potwierdzone. To nie jest jakieś odgrywanie, wobec którego zachowuję radykalny dystans, ponieważ jest ono bardzo głęboko umiejscowione i psychicznie zakorzenione; to „Ja” nie odgrywa swego lesbianizmu jak jakiejś roli. Raczej poprzez powtarzane odgrywanie tej seksualności „Ja” jest uporczywie rekonstytuowane jako „Ja” lesbijskie ${ }^{40}$.

Tożsamość, także homoseksualna, tworzy się zatem w performatywnym akcie subwersywnych powtórzeń - idealna imitacja jest przecież niemożliwa. Figura powtórzenia zakłada nieciągłość, wiele może się wydarzyć między jednym a kolejnym momentem emanacji danych obszarów ,ja”, jego ujawniania się ${ }^{41}$. Ujawniania się nie tylko przed samym sobą, ale także wobec innych, którzy stają się świadkami/odbiorcami tego procesu, mającymi zasadniczy wpływ na jego przebieg. Myślę, że właśnie w interwale między kolejnymi powtórzeniami wytwarza się przestrzeń albo dla sublimacji, jak w Sońce, gdzie jedyne

39 D. Nowacki, ,,Miłość” Ignacego Karpowicza...

40 J. Butler, Imitacja i niepostuszeństwo ptciowe, przeł. E. Majewska, „Przegląd Filozoficzno-Literacki” 2003, nr 1, s. 95.

${ }^{41}$ Używam sformułowania ,dane obszary ja”, nie zaś pojęcia ,ja” jako takiego, bo skoro jest coś, co tymi powtórzeniami dysponuje, oznacza to - jak zauważa Butler - że się ono w nich nie wyczerpuje. 
dostępne dla Igora ,powtórzenie”, dzięki któremu mógł się (pośrednio) wyrazić, stanowiła Sonia, albo dla autentyczności, jak w książce Miłość (tyle że, jak się za chwilę okaże, specyficznie rozumianej).

W Sońce, o czym już wielokrotnie była mowa, autentyczność stanowiła jeden z najważniejszych tematów samej powieści, realizowany w dużej mierze na poziomie metatekstowym, na którym Karpowicz z okrutną wręcz wobec czytelnika pedanterią obnażał mechanizmy wytwarzania efektu prawdy i sposoby wzruszania odbiorców. W Miłości autentyczność ma zostać w pełni zrealizowana i ,skonsumowana” przez bohaterów, co finalnie doprowadzi do jej przeformułowania w pokrewną, a jednak zgoła odmienną strategię: szczerość ${ }^{42}$. Formalnym sygnałem tej transformacji wydaje się zastosowanie narracji pierwszoosobowej. Tak mówi o tym sam Karpowicz w tekście Jak napisałem powieść o miłości pod tytułem „,Miłość”, w którym odsłania tajniki powstawania tej książki (fakt opublikowania tego rodzaju autokomentarza można potraktować jako jeden z elementów „strategii szczerości”), zwierzając się między innymi z tego, że pisał ją przez pięć lat, a całą pierwszą wersję tekstu zniszczył, nie mogąc znaleźć właściwego „tonu”:

Nie rozumiem, dlaczego znowu napisałem dwieście stron do niczego.

Te solennie opisane poruszenia duszy, te najtkliwsze rozmowy poruszają z siłą muszego gówienka. Nuda i fałsz wyzierają z każdego słowa. Z tego związku chemii nie będzie.

Wreszcie istota kłopotu się ujawnia. Trzecioosobowa narracja! Ona odkleja się od bohaterów. Zsuwa po nich jak po maśle.

Odpalamy! Witaj, Delete!

Za późno na odwrót.

42 Jak zauważa Michał Warchala, szczerość bywa traktowana jako „,równoważnik autentyczności”, tymczasem jest wobec niej nie tylko czymś odrębnym, ale wręcz przeciwstawnym, pozostając w bliskiej relacji z takimi pojęciami, jak naturalność czy spontaniczność. Warchala, uznając ideę autentyczności za ,przewodni motyw nowoczesnego poszukiwania fundamentu jednostkowej tożsamości”, odtwarza - wychodząc od Rousseau, a na Nietzschem kończąc, z romantyzmem jako kluczowym momentem tego procesu ewolucję ,języka, w którym jednostka może dokonać zapisu siebie”. Zob. idem, Autentyczność i szczerość, Kraków 2006, s. 20, 21.

Usytuowanie Sońki i Miłości na tle fundujących nowoczesność koncepcji autentyczności i środków jej wyrazu to temat na osobną rozprawę.

Na prawach synonimów używa słów „autentyczność” i „szczerość” Marek Kochanowski w artykule $W$ poszukiwaniu autentyczności. Powieści Ignacego Karpowicza, poświęconym Niehalo, Gestom oraz Balladynom i romansom. Badacz interpretuje autentyczność jako jedną z pożądanych cech ludzkich relacji, której brak dotkliwie odczuwają niemal wszyscy bohaterowie omawianych powieści. Zob. M. Kochanowski, W poszukiwaniu autentyczności. Powieści Ignacego Karpowicza [w:] Wiktor Choriew in memoriam, red. A. Janicka, G. Kowalski, Ł. Zabielski, Białystok 2013, s. 395-403. 
Nie ma zmiłuj. Skosztować przyjdzie narracji pierwszoosobowej. Choć do tego trybu dawno temu nabrałem daleko idących podejrzeń. Niepokoją mnie pozorna łatwość emocji i niedyskretne skrócenie dystansu między bohaterem a odbiorcą. Narrator jako nieproszony napraszający się gość w twoim domu ${ }^{43}$.

Jak pamiętamy, w Sońce Karpowicz zastosował wiele środków, żeby zwiększyć dystans między bohaterami a odbiorcą, w Miłości robi dokładnie odwrotnie. Zawarty z czytelnikiem ponad tekstem tej pierwszej powieści ,pakt autentyczności” był niejawny, „pakt szczerości” oferowany jest mu wprost, choćby w takiej deklaracji:

Będę zadowolony, jeśli zapytacie, czy Miłość to moja historia. Jeśli zadacie to pytanie, poczuję, że udało się stworzyć efekt intymności i szczerości, na którym zależało mi najbardziej. Uwierzcie - w literaturze nic nie przychodzi trudniej ${ }^{44}$.

Słowo „szczerość” pada też w rozmowie z Dorotą Wodecką, kiedy na wzmiankę o tym, że nowa książka jest ,wzruszająca”, Karpowicz odpowiada: „Wzruszenie można potraktować jako produkt uboczny szczerości”45. Opowiada również o tym, jak trudne zadanie przed sobą postawił, bo szczerość, intymność i skracanie dystansu bynajmniej nie oznaczają uproszczenia zasad reprezentacji i referencji, a wprost przeciwnie:

[...] literatura i życie idą pod ramię, ale nie w skali jeden do jednego. Pisząc „Miłość", zrobiłem test. Zapisałem w trybie non-fiction tydzień mego życia, szczęśliwie akurat bez większych tąpnięć. I okazało się, że to jest kompletnie niewiarygodne. Moje prawdziwe życie po spisaniu okazało się niewiarygodne!

Żeby tekst stał się prawdziwy, musi ulec oddzieleniu od realu. Jak mówi Julian Barnes: powieść to kłamstwo, które mówi prawdę ${ }^{46}$.

Strategia szczerości wymaga też rezygnacji z ironii, która była znakiem rozpoznawczym twórczości Karpowicza, stanowiąc, jak to przyznaje sam pisarz, formę obrony i asekuracji, jego osobisty „,puklerz”.

Miłość rzeczywiście realizuje wszystkie sformułowane przez autora postulaty. Pierwszoosobowy narrator relacjonuje proces odkłamywania własnej tożsamości płciowej, czyli „stawania się gejem, mimo że się nim zawsze było”, jak by to określiła Butler. Właściwie umiera i rodzi się na nowo, historia jego

43 I. Karpowicz, Jak napisałem powieść o miłości pod tytułem „,Miłość”, „Książki. Magazyn do czytania” 2017, nr 4, https://wyborcza.pl/ksiazki/7,154165,22671295, ignacy-karpowicz-jak-napisalem-powiesc-o-milosci-pod-tytulem.html [dostęp: 25.06.2020].

44 Ibidem.

45 I. Karpowicz, Polskość jest jak Freddy Krueger...

46 Ibidem. 
spotkania ze Zbyszkiem i ich wzajemnej miłości toczy się bowiem symultanicznie z opowieścią o zatorze tętniczym i pobycie w szpitalu. Dowiadujemy się o dramacie zinterioryzowanej homofobii, problemach z własnym ciałem i sublimacji realizowanej za pośrednictwem literatury:

Przestałem uprawiać seks. Seks uprawiałem w pisanych tekstach. [...] Nie da się unikać siebie, będąc sobą i w sobie. Konieczne jest znalezienie jakiegoś innego miejsca albo przestrzeni, innego punktu odniesienia, w którym wreszcie można z ulgą stracić się z pola widzenia. [...] Tym schronieniem była literatura. [...] To w niej i dzięki niej mogłem wydłubywać mozolnie lepsze światy i piękniejsze miłości, a siebie mogłem wydłubać z bieżącej rzeczywistości i lęku ${ }^{47}$.

Jak relacjonowałam na początku, Piękno, Prawda i Dobro, każdy z rozdziałów realizujący inną formę literacką, niczym lustra odbija i doświetla, a zarazem - uniwersalizuje pierwszoosobową opowieść o coming oucie. Luster i szyb jest zresztą $\mathrm{w}$ tej powieści bardzo dużo, nawet w części najbliższej konwencji realistycznej. Żeby uniknąć w niej niechcianej dosłowności, Karpowicz „wywraca miasto na drugą stronę” i tworzy „lustrzany świat, bardzo podobny do naszego. Nie Katowice, ale Kattowitz!"48.

Otwarte pozostaje pytanie, co z tego wynika? Przemysław Czapliński dostrzega w tej powieści próbę, nie do końca udaną, ale niezwykle ważną, bo sygnalizującą kierunek, w jakim powinna podążać sztuka - odnowienia języka literatury przez przepracowanie ironii, która stała się niezbywalnym elementem ponowoczesnego dyskursu, ale też okazała się bezsilna w zetknięciu z radykalnymi narracjami (na przykład z narracją nacjonalistyczną), zyskującymi coraz więcej zwolenników. Zdaniem Czaplińskiego, dzięki odwadze nazywania Piękna, Prawdy i Dobra bez użycia ironicznych nawiasów, udało się Karpowiczowi pogodzić utracony przez inteligencję absolut - z ironią, występującą w roli narzędzia sprawdzającego wartość jego własnych deklaracji. Interpretując postać pierwszoosobowego narratora, badacz twierdzi, że pisarz skonstruował podmiot ,zbudowany [...] na prawie dostępu do samego siebie”, który „stawia przed sobą wymóg szczerości”. „Trzeba pielęgnować siebie, aby móc pielęgnować demokrację - taki mniej więcej wyciągnąć z tej powieści można wniosek", pointuje swoje rozważania Czapliński, dodając jeszcze, że Karpowicz pokazał nam możliwość odzyskania dla literatury „swoistych form pierwszych", takich jak realizm psychologiczny, antyutopia i baśn ${ }^{49}$.

$\mathrm{Na}$ antypodach tych rozważań sytuuje się bardzo krytyczna recenzja Łukasza Żurka, który zarzuca Miłości pretensjonalność, a jej autorowi cynizm

47 I. Karpowicz, Miłość, Kraków 2017, s. 95-96.

48 Idem, Jak napisatem powieść o miłości...

49 P. Czapliński, Ironia i absolut, „Dwutygodnik” 2018, nr 1, http://www.dwutygodnik.com/artykul/7591-ironia-i-absolut.html [dostęp: 26.06.2020]. 
w posługiwaniu się strategią szczerości, mającą usprawiedliwić powieściowe niedociągnięcia, wtórność i melodramatyczną strukturę. Zdaniem krytyka wszystkie części powieści zbudowane zostały na schemacie pokonywania przez kochanków zewnętrznych przeszkód, stojących na drodze ich miłości. Cała reszta to zabawa z czytelnikiem, a raczej - jak to złośliwie ujmuje - czytelniczką, co ma na celu zapewnić jej złudzenie, że nie obcuje ze szmirą, lecz ambitną literaturą środka. Ostatni ze sformułowanych przez Żurka zarzutów wydaje się najpoważniejszy:

Z tego powodu Mitość nie sprawdza się na polu, na którym miałaby szansę stanowić nową wartość w polskiej literaturze - jako wysokonakładowa powieść o polskiej homofobii. Nie sprawdza się, bo niczego nie przekracza, niczego nie kwestionuje, za to potwierdza status quo: miłość homoseksualna to miłość heteroseksualna z dodatkową dawką cierpienia. [...] Jednowymiarowy świat Miłości Karpowicza, tak silnie pozorujący wielowymiarowość, poprzez swoje wewnętrzne zamknięcie jest symptomem (a nie - jak chciałby Czapliński - przezwyciężeniem) anomii polskiego dyskursu politycznego: niemożności innego myślenia - o sobie jako zbiorowości i jednostce, świecie, kulturze $^{50}$.

Nie udało się zatem Karpowiczowi, zdaniem Żurka, obnażyć dyskursywnych podstaw mechanizmów wykluczania, działających w polskim społeczeństwie. Być może (to już moja intuicja) stałoby się inaczej, gdyby szczerość nie zastąpiła autentyczności.

Nie przywołuję tych dwóch skrajnych opinii po to, by opowiedzieć się po stronie któregoś z recenzentów, ale żeby pokazać, jakie ryzyko wiąże się z zastosowaniem „strategii szczerości” i jak odmienne reakcje może ona sprowokować. Wydaje się jednak, że niejako immanentnie wpisane jest w nią ryzyko narcyzmu, zagłuszania cudzych głosów w imię prawa do ekspresji własnego, czego symbolem - nie wiem, w jakim stopniu świadomie zastosowanym - stają się w Mitości lustra i przeglądający się w nich bohaterowie.

Już spełniony i zakochany narrator, wprowadziwszy się do mieszkania Zbyszka, mówi:

Zamykam szafę, ta jednak uparcie się otwiera. Skrzydło raz po raz odsłania niezamieszkane wnętrze, jakby szafie nie było końca, a ja właśnie chciałbym tam wejść, a nie wyjść. Chciałbym zamieszkać w tej szafie i mówić z niej prawdę ${ }^{51}$.

50 Ł. Żurek, Powieść jako nieudana próba bycia serio oraz jako symptom bardzo smutnych rzeczy, „Mały Format” 2018, nr 1, http://malyformat.com/2018/01/powiesc-jako-nieudana-proba-bycia-serio-oraz-jako-symptom-smutnych-rzeczy/ [dostęp: 26.06.2020].

51 I. Karpowicz, Miłość, s. 209. 
Nie jest to oczywiście mebel przypadkowy - jako „wyjście z szafy” określa się coming out. Pragnienie pozostania w niej można interpretować na wiele sposobów. $Z$ jednej strony symbolizuje ono zagrożenie ze strony świata, zwłaszcza wobec tych, którzy pragną być szczerzy i żyć w zgodzie ze sobą, $z$ drugiej - odcięcie od niego, skupienie wyłącznie na tym, co własne, podmiotowe; niemal solipsyzm. Z perspektywy otwartej szafy, przypominającej pudło rezonansowe, świat może się wydać przydatny i istotny przede wszystkim jako przestrzeń służąca manifestacji własnej szczerości.

„Autentyczność to jednak potworna klisza”, pisał w Sońce Karpowicz. Ale coś sprawia, że - jak zauważa Szmidt - jej idea

[...] - dyskredytowana, ale nigdy ostatecznie nieporzucona - powraca w najmniej, wydawałoby się, oczekiwanych momentach. Przesileń, kryzysów, narastającego niepokoju. Zarówno tych indywidualnych czy osobistych, jak i ujmowanych w większej skali - narodowej, społecznej czy nawet globalnej ${ }^{52}$.

Potwierdzeniem tej intuicji wydają się obie interpretowane wyżej powieści, z których każda realizuje inny model autentyczności. Za każdym razem jednak sięga Karpowicz po tę strategię w poczuciu jej literackiej i etycznej skuteczności.

\section{Bibliografia}

Butler J., Imitacja i niepostuszeństwo ptciowe, przeł. E. Majewska, „Przegląd Filozoficzno-Literacki" 2003, nr 1.

Czapliński P., Ironia i absolut, „Dwutygodnik” 2018, nr 1, http://www.dwutygodnik. com/artykul/7591-ironia-i-absolut.html [dostęp: 26.06.2020].

Czapliński P., Nowa powieść Ignacego Karpowicza. Jak wyjść z kopalni trupów, „Gazeta Wyborcza”, 20.05.2014, https://wyborcza.pl/1,75410,15992693,Nowa_powiesc_Ignacego_Karpowicza_Jak_wyjsc_z_kopalni.html_[dostęp: 26.06.2020].

Czermińska M., Autobiograficzny trójkąt. Świadectwo, wyznanie, wyzwanie, wyd. 2 zmien., Kraków 2020.

Eribon D., Powrót do Reims, przeł. M. Ochab, Kraków 2019.

Gontarz B., Meandry etyczne podmiotu w ,Sońce” Ignacego Karpowicza [w:] „Ja”, $w$ przestrzeniach aksjologicznych. Z problematyki podmiotowości $w$ literaturze XIX-XXI wieku, red. L. Zwierzyński, M. Wiszniowska, P. Paszek, Katowice 2017. Karpowicz I., Jak napisałem powieść o miłości pod tytułem „Miłość”, „Książki. Magazyn do czytania" 2017, nr 4, https://wyborcza.pl/ksiazki/7,154165,22671295, ignacy-karpowicz-jak-napisalem-powiesc-o-milosci-pod-tytulem.html [dostęp: 25.06.2020].

Karpowicz I., Miłość, Kraków 2017.

52 O. Szmidt, op.cit., s. 17. 
Karpowicz I., Polskość jest jak Freddy Krueger - zawsze wraca i tnie, rozmawia D. Wodecka, „Gazeta Wyborcza”, 17.11.2017, https://wyborcza.pl /7,75517,22661462,ignacy-karpowicz-polskosc-jest-jak-freddy-krueger-zawsze. html?bo=1 [dostęp: 25.06.2020].

Karpowicz I., Sońka, Kraków 2014.

Kochanowski M., W poszukiwaniu autentyczności. Powieści Ignacego Karpowicza [w:] Wiktor Choriew in memoriam, red. A. Janicka, G. Kowalski, Ł. Zabielski, Białystok 2013.

Koziołek R., Esesman, mój bliźni [w:] idem, Dobrze się myśli literatura, Wołowiec 2016.

Lejeune P., Pakt autobiograficzny, przeł. W. Labuda, „Teksty” 1975, nr 5.

Nowacki D., „Miłość” Ignacego Karpowicza. M jak miłość, m jak majstersztyk, „Gazeta Wyborcza", 20.11.2017, https://wyborcza.pl/7,75517,22669463,milosc-czyli-wyzwolenie-nowa-powiesc-ignacego-karpowicza.html [dostęp: 25.06.2020].

Ritz G., Niewypowiadalne pożąanie a poetyka narracji, przeł. A. Kopacki, „Teksty Drugie" 1997, nr 3.

Sawicka-Mierzyńska K., Poruszyć miejsce. Obraz Białegostoku w twórczości Sokrata Janowicza i Ignacego Karpowicza, Białystok 2018.

Szmidt O., Autentyczność: stan krytyczny. Problem autentyczności w kulturze XXI wieku, Kraków 2019.

Śmieja W., Literatura, której nie ma. Szkice o polskiej literaturze homoseksualnej, Kraków 2010.

Warchala M., Autentyczność i szczerość, Kraków 2006.

Wróbel Ł., ,,Sońka”, czyli spokój czasu przeszłego. O najpiękniejszej powieści Ignacego Karpowicza, „Kultura Liberalna” 2014, nr 29, https://kulturaliberalna.pl/ 2014/07/22/sonka-karpowicz/ [dostęp: 26.06.2020].

Zawojska G., ,Sońka” Ignacego Karpowicza w kontekście wybranych koncepcji feminizmu postmodernistycznego, „Białostockie Studia Literaturoznawcze” 2019, nr 14.

Żurek Ł., Powieść jako nieudana próba bycia serio oraz jako symptom bardzo smutnych rzeczy, „Mały Format” 2018, nr 1, http://malyformat.com/2018/01/powiesc-jako-nieudana-proba-bycia-serio-oraz-jako-symptom-smutnych-rzeczy/ [dostęp: 26.06.2020]. 